\title{
Polygamy in Muslim Countries: A Comparative Study in Tunisia, Saudi Arabia, and Indonesia
}

\author{
Muhammad Roy Purwanto \\ Department of Akhwal Asy-Syakhsiyah, Faculty of Islamic \\ Studies \\ Islamic University of Indonesia \\ Yogyakarta, Indonesia \\ muhammadroy@uii.ac.id \\ M. Roem Syibly \\ Department of Akhwal Asy-Syakhsiyah, Faculty of Islamic \\ Studies \\ Islamic University of Indonesia \\ Yogyakarta, Indonesia \\ roemsyibly@uii.ac.id
}

\author{
Tamyiz Mukharrom \\ Department of Akhwal Asy-Syakhsiyah, Faculty of Islamic \\ Studies \\ Islamic University of Indonesia \\ Yogyakarta, Indonesia \\ tamyiz_mukharrom@uii.ac.id \\ Ahmad Nurozi \\ Department of Akhwal Asy-Syakhsiyah, Faculty of Islamic \\ Studies \\ Islamic University of Indonesia \\ Yogyakarta, Indonesia \\ 153110504@uii.ac.id
}

\begin{abstract}
This study intends to describe polygamous laws in Muslim countries such as Tunisia, Saudi Arabia, and Indonesia. In general, the provisions (legislation) relating to family law in modern Muslim countries are linked to polygamous rules, something that can be classified into three. Firstly, countries that completely prohibit the practice of polygamy such as Turkey and Tunisia. Secondly, countries that allow polygamy with relatively strict (complicated) conditions such as Pakistan, Egypt, Morocco, Indonesia and Malaysia. Thirdly, countries that more loosely handle polygamy, such as Saudi Arabia, Iran and Qatar. This research, used samples from three countries representing three approaches to law in response to polygamy: Tunisi, Indonesia, and Saudi Arabia. The results of this study were as follows; first, the Tunisian Family Law prohibits polygamy, the Indonesian Family Law allows polygamy under strict conditions, and the Saudi Family Law allows polygamy without strict restrictions. Secondly, majority of the citizens follow the laws applying in their country on polygamy. As a result, Tunisians are not polygamous and very few Indonesians practice it in while in Saudi Arabia, it is a common practice.
\end{abstract}

Keywords: polygamy, reform, family law, Islamic law

\section{INTRODUCTION}

The reformation on family laws have been carried out in Muslim countries due to the demands of the ages and modernity.[1] The review of the number of classical Islamic law provisions considered to be irrelevant to the recent social conditions is one of its required stage.[2]

According to Tahir Mahmood, there are thirteen aspects related to the family law reformation, i.e. the minimum age for marriage, limitation on the role of guardians in marriage, the need for marriage registration, the economic ability, the weaknesses of polygamy, the family income, the limitations on rights and obligations of the parties due to divorce, the gestation period and its implications, the rights of the guardians or the parents, the right of inheritance of the family, the mandatory will, and management of work.[3]

One of the problems concerning reforming Islamic law is polygamy. The conventional rules about it are now being reviewed and replaced with the new legislations. It is directed as an efforts to elevate the status of women and also as the respond to the demands and development of the new error.[4]

In general, family law in modern Muslim countries related to polygamy can be classified into three. First, countries that completely prohibit polygamy, such as Turkey and Tunisia. Second, countries that allow polygamy with relatively strict conditions, such as Pakistan, Egypt, Morocco, Indonesia and Malaysia. Third, countries that entertain polygamy, such as Saudi Arabia, Iran and Qatar.[5]

This present study took Tunisia, Indonesia and Saudi Arabia as the sample representing the three aforementioned approaches toward poligamy. Tunisia represents countries that completely prohibit poligamy. On the other hand, Indonesia stands in place of countries allowing poligamy with a certain requirements while Saudia represents the countries that are quite lanient towards poligamy.

\section{RESEARCH METHODS}

This is a literature study that compares Marriage Laws in Tunisia, Indonesia and Saudi Arabia. The sources of data in this study involved both primary and secondary. The primary sources were The Code of Personal Status in 1958 Tunisia, Law No.1 in 1974 on the Marriage and Compilation of Islamic Law in 1991, Indonesia, and Marriage Law of Hanafi Madzhab in Saudi Arabia. The secondary ones were obtained from several reference sources such as journals, books, research results, and other written materials related to polygamy in three countries.

\section{RESULTS}

\section{A. Poligamy and Clasical Fiqh}

The term of poligamy is derived from Latin verbs polygamia (poly and gamia)[6] or a combination of the Greeak poly dan gamy from polus (many)[7] and gamos (married).[8] Therefore, in etimology polygamy refers to the marriage in large entities. Still, it is a marriage condition to have more than one wife, husband at the same time in terminology.[9] In KBBI, it is defined as a marriage system 
where one of parties (wife or husband) marry several person at the same time.[10]

In The Encyclopedia Americana stated:[11] "Polygamy is a form of union in which one male is married to more than one female while polyandry is a form of Poligamy in which one female is married to more than one male." According to the classical scholars, polygamy is something mubah and not prohibited. In general, the focus of discussion in the literature is not on the allowance of polygamy but rather the maximum number of wives that one can marry. It is a result of differences in understanding the Qur'anic verses which contain the issue of polygamy (S. an-Nisa: 3).[12]

Some schoolars state that the number of wives in polygamous union should be four. This is based on the instructions of the verse matsna wa tsulasa wa ruba' (Q.S. anNisa: 3). It is also based on the hadith from Gailan ibn Salamah which asserts that the Prophet was asked to choose and retain four of the ten wives he owned during the Jahiliyah period (before Islam) and divorce the remaining ones (Hadith editors will be shown in the next description). In addition, another group of scholars, based on the same clue, argues that the maximum number of wives should be 9 people. They suggest that the verse phrase matsna wa tsulasa wa ruba 'shows the cumulative meaning $(2+3+4=9)$. Therefore, one man may marry nine women. [13]

The various fiqh reviews tend to contain the conditions that must be fulfilled by husbands who want to be polygamous including material abilities and the obligation to be fair.[14] A relatively similar attitude is also shown by the mufassir or interpreters (particularly in classics) when acknowledging these nasal statements. The various descriptions of this problem seem to be closely related to their understanding and interpretation of a number of statements from the Qur'an and as-Sunnah.

In addition to the issue of the maximum number of wives, there are almost no differences in interpreting the verses of the Qur'an related to polygamy. The majority of scholars asserts that the maximum number of wives in polygamous marriage is four. Still, some other scholars (minorities), eg. ar-Rafidhah (one of the syi'ah sects) argue that the maximum number is nine. There is also another opinion that stated a total of eighteen wives is acceptable.[15] Based on these opinions, it is evident that the majority of classical scholars do not question polygamy. They argue that polygamy is permissible if the the fair requirement is met.

\section{B. Polygamy in Muslim countries}

Regarding family law reformation, JND. Anderson states that Muslim countries in the world are divided into three categories. The first class is that of countries that have not reformed Islamic law at all. They continue to apply the laws contained in the fiqh books based on madzhab eg. Saudi Arabia, Oman and Qatar. The second category is that of countries that have abandoned Islamic laws and replaced them with secular ones commonly applied in Europe. Turkey and Tunisia are two of the countries in this class. Third, some countries have reformed Islamic law by combining it with secular ones. It is included Egypt, Tunisia, Iraq, Syria, and Indonesia.[16]

Taheer Mahmoud in Muslim Family Law Reform also stated that there are three groups of Muslim countries related to the application of the family law, i.e.: (1) Countries that apply family and marital law from various madhab they adhere to, and have not been changed; (2) Countries that have totally changed their family and marriage law with a modern ones, with no regards to their religion; (3) Countries that apply the Islamic family and marriage law reformed with various modern legislative processes.[17]

Based on these facts, there are Muslim countries that still continue to use the conventional Islamic law determination methods, though some have used the modern ones. Furthermore, there are several characteristics of the conventional Islamic law such as (a) Using a partial, atomistic approach or juz'I, (b) Less attention to history (ahistory), (c) Overemphasizing on the text or literalistic study. (d). The method of fiqh seems to be separate from the methodology of interpretatio, (e). Too much influenced by local cultures and traditions, and in some cases it permits the practices of bid'ah and kufarat, especially those relating to 'worship', and (f). The entry of political elements and the influence of the interests of the authorities

\section{1) Tunisia}

Tunisia has attracted the attention of the Islamic world in banning polygamy. The rule for its prohibition is contained in article 18 of The Code of Personal Status of 1958 which regulates the marriage and inheritance law. It states: "To having more than one wife is prohibited. Anyone who has remarried before the first marriage is legally separated can be sentenced to a one-year prison or a fine of 240,000 malims or both".[18]

The article above explicitly indicates polygamy is prohibited. This move has a legal basis in the Qur'an in a verse stating that a man is obliged to marry only a wife if he believes that he is not able to deal justly with his wives (Q.S.-an-Nisa [4]: 3). Apparently, both from experience and revelation statements (Q.S.-an-Nisa [4]: 128), the intended justice is never be fulfilled.[19] Based on the the aspect of justice in polygamy, the marriage law in Tunisia prohibits men from polygamy. Anyone who commits polygamy is considered a criminal who can be imprisoned and be fined.

\section{2) Indonesia}

In Indonesia, polygamy is regulated in Article 3 paragraph (1) and (2) of the Marriage Law No.1 in 1974. It states that in principle, in a marriage a man may only have a wife while a woman can only have a husband. The court can give permission to a husband to marry more than one person if it is desired by both parties (husband and wife). Furthermore, it mentions in Article 4: (1)in a that a husband will have more than one wife, he is obliged to submit an application to the Court in his area of residence. (2)The court referred to in paragraph (1) of this article only grants permission to a husband who will marry more than one person if: a. wife cannot carry out her obligations; $b$. the wife gets a disability or an incurable disease; c. the wife cannot give birth. Similarly,, in Article 5 (1): To submit an application to the Court, as referred to in Article 4 (verse 1), the following conditions must be fulfilled: a. The approval from wife/wives; b. there is a certainty that the husband is able to guarantee the necessities of life of his wife and their children; c. there is a guarantee that the husband will be fair to their wives as well as children.[20] 
In the government regulations PP No.9 in 1975 article 40, it is stated that if a husband intends to have more than one wife, he is obliged to submit a request in writing to the court. These provisions basically complicate the who act of polygamy. For Civil Servants (PNS), based on PP No. 10 in 1983, polygamy was practically prohibited. Article 3 paragraph (1) it is states that: Civil servants who wants to divorce must obtain prior permission from the official. Still, Article 4 stipulates that: (1) Male civil servants who will have more than one wife, must obtain prior permission from officials. (2) Female civil servants are not permitted to be the second/third/fourth wife of civil servants. Whereas Article 16 affirms: Civil Servants who violate the provisions of Article 3 paragraph (1) and Article 4 paragraph (1), (2), and (3) are subject to disciplinary penalties that may entail dishonorable dismissal as Civil Servants. This Government Regulation has now been revised by PP No. 45/1990 on Amendments to Government Regulation No.10 / 1983. It changes the provisions of Article 16 and subsequently made a new Article 15 provisions. Its paragraph (1) states: Civil servants who violate one more provisions of Article 2 paragraph (1) and (2), Article 3 paragraph (1), Article 4 paragraph (1), and Article 14 , not reporting his divorce, and not reporting his second / third / fourth marriage within a period of 1 year from the date the marriage was proceeded, based on PP No.30/1980 concerning Civil Servant Discipline Regulations; paragraph (3): Offenders who violate the provisions of Art.5 paragraph (2), and Officials who violate the provisions of Article 12 are subject to severe disciplinary penalties. This is in harmony with based PP No. 30/1980 on Civil Servant Discipline Regulations.[21]

In the Compilation of Islamic Law, polygamy is regulated in articles 55-59. These articles are in accordance with the provisions regulated by Constitutions No. 1/1974 Article 3, 4 and 5, indicating that polygamy in Indonesia is permitted, but with very strict requisites.

\section{3) Saudi Arabia}

Different with the two countries above, Saudi Arabia allows polygamy if fairness is guaranteed and only limited to four wives. The country do not have a specific law to deal with this problem. Polygamy is permitted for men but is limited to four wives at one time. Due to the "lenient" state law on this issue, the practice has increased, especially among the educated people, due to oil resources.[22] Even, the Government of Saudi Arabia has promoted polygamy as a way of returning to the "Islamic values" program. In 2001, Grand Mufti issued a fatwa, or opinion, calling on Saudi women to accept polygamy as part of the Islamic package and stated that the act was needed "to fight the growth of the spinster epidemic".

This polygamy acquisition occurs because the marriage law in Saudi Arabia is still uncodified law. It means that the marriage law is still based on the book of fiqh madhab, especially Hambali's madhab as the official Madhab of the State. It is not based on the Marriage Law as in Tunisia and Indonesia.[23].

\section{CONCLUSIONS}

According to classical fiqh scholars, polygamy is mubah and not prohibited. However, it is accompanied by requirements of being able to do justice and economic capabilities of the interested parties. A relatively similar attitude was shown by the mufassir who allowed polygamy based on the interpretation of the text of the Qur'an and alHadith.

In general, the family law in modern Muslim countries related to polygamy can be classified into three: countries that completely prohibit the practice (Turkey and Tunisia), those that allow it with relatively strict conditions (Pakistan, Egypt, Morocco, Indonesia and Malaysia) and the ones that handle it more loosely (Saudi Arabia, Iran and Qatar).

\section{REFERENCES}

[1] J. N. D. Anderson, Islamic Law in the Modern World, (New York: New York University Press, 1959), 3;

[2] Wael B. Hallaq, "Was the Gate of Ijtihad Closed", dalam International Journal of Middle East Studies, No16 (1984), 3.

[3] Tahir Mahmood, Personal Law in The Muslim Countries, (New Delhi: Triomies Press, 1987), 11-12.

[4] Tahir Mahmood, Family Law Reform in the Muslim World (Bombay: N. M. TRIPATHI PVT. LTD,1972), 17.

[5] Tahir Mahmood, Personal Law in Islamic Countries: History, Texs and Comparative Analysis, (New Delhi, Academy of Law and Religion New Delhi ,1987), 273274; Norman Anderson, Law Reform in the Muslim World, (London: The Athlone Press, 1976)

[6] William Morris, The Heritage Illustrated Dictionary of the English Language, Vol. II, Houghton Mifflin Campany, Boston, 1979, hlm. 1016.

[7] Arif Rohman, "Reinterpret Polygamy in Islam: A Case Study in Indonesia", in International Journal of Humanities and Social Science Invention, Volume 2 Issue 10, October 2013, p. 68.

[8] Rachel Jones, "Polygyny in Islam", in Macalester Islam Journal, Volume 1, issue 1, 2006, p. 2.

[9] Tim Depdikbud, op. cit., hlm. 885.

[10] Bernard S. Cayne (Ed.), The Encyclopedia Americana, vol. XVIII, Grolier Incorporated, New York, 1996, 345.

[11] Ibn Rusyd, Bidayat al-Mujtahid wa Nihayat alMuqtashid, juz II, (Dar al-Fikr, Beirut, 1995), 33.

[12] Heather Johnson, "There are Worse Things Than Being Alone: Polygamy in Islam, Past, Present, and Future", in William \& Mary Journal of Women and The Law, Volume 11, Issue 3, 2005. p 564

[13] Marzuki, "Poligami dalam Hukum Islam", Jurnal Fakultas Ilmu Sosial dan Ekonomi, UNY, 2015.

[14] al-Qurtubi, al-Jami' li Ahkan al-Qur'an, juz V, (Kairo: t.p. t.t.), 17.

[15] J. N. D. Anderson, Islamic Law in the Modern World, (New York: New York University Press, 1959), 3; Wael B. Hallaq, "Was the Gate of Ijtihad Closed", dalam International Journal of Middle East Studies, No16 (1984), 3

[16] Tahir Mahmood, Family Law Reform in The Muslim World, (Bombay: Tripathi, 1972), hlm. 2-3

[17] John P. Entelis, "Tunisia” dalam John L. Esposito (Ed.), The Oxford Encyclopaedia of the Modern Islamic World, jld IV, Oxford University Press, 1991.

[18] Norman Anderson, Law Reform in the Muslim World, (London: The Athlone Press, 1976), 63; J.N.D. Anderson, "The Tunisian Law of Personal Status", dalam International and Comparative Law Quarterly, 7 April $1985,262$.

[19] Nur Hayati, "Poligami dalam Perspektif Hukum Islam; Perspektif Undang-Undang Perkawinan", Lex Jurnalica, Vol. 3. No. 1, 2005, 38.

[20] Reza Fitra Ardhian, Satrio Anugrah, Setyawan Bima, "Poligami dalam Islam dan dalam Hukum Positif Indonesia Serta Urgensi Pemberian Izin Poligami di Pengadilan Agama", in Privat Law Vol. III No 2 JuliDesember 2015, p. 100. 